\title{
On the Fragility of the Civilization in William Golding's Lord of the Flies
}

\author{
XU Jian-gang, ZOU Cheng-bo \\ China Three Gorgeous University, Yichang, China
}

\begin{abstract}
Lord of the Flies, which is one of the representatives of William Golding, describes that a group of children, trapped on a desert island, have gradually divided into two parties. The one represents civilization, reason and salvation, The other represents primitivity and wilderness. As a result, the first side is defeated by the latter one and the civilization on the island has been destroyed. This paper will illustrate the fragility of the civilization reflected from Lord of the Flies from three aspects. They are the civilized background, social subjects and reasons why the civilization has been destroyed respectively.
\end{abstract}

Keywords: desert island, civilization, the fragility of the civilization

\section{Introduction}

The novel Lord of the Flies reflects the fragility of the civilization from the point of reality by the odd story lines. None of the characters in the book is perfect. In other words, Lord of the Flies is opposed to aestheticism novels (DUAN, 2007). The novel is backgrounded by a futuristic nuclear war. In the process of evacuation, a group of boys around six to twelve years old catching a plane from the mainland Britain to the south, but the plane was shot down and the children fell into an island, beautiful but desolate. Primarily, the group of children pulled together and they worked together. However, afterwards, they were split into two parties due to their terror of a so-called "monster". Some boys didn't tend to establish a democratic and orderly society with civilization, instead, they started to deteriorate into savages, who threw away all plans which were made primarily and killed Simon and Piggy. Eventually, the civilization of the island vanished. This paper will demonstrate the fragility of civilization reflected in the novel from the civilized background, social subjects and reasons why the civilization is destroyed respectively.

\section{The Civilized Background in Lord of the Flies: The Desert Island}

The desert island is a particular background which can obviously manifest the nature of human beings. Since the desert island is situated in remote locations, inhabited and isolated from the real world, so it can be seen as the pure environment of human civilization, without any restraints from any existing regime. So, in this situation, the relation between human and nature as well as the relation between person to person of the novel can be thoroughly illustrated. All boys survived on the island are the representatives of human beings and different aspects of human nature can be perceived from them. At the background of the desert island, the

XU Jian-gang, Professor, Institute of Foreign Languages, University of China Three Gorgeous University.

ZOU Cheng-bo, postgraduate, Institute of Foreign Languages, University of China Three Gorgeous University. 
situations and problems people faced with can be expressed refinedly through the behaviors of the protagonists so as to demonstrate human nature. The desert island, which is far away from any human habitation, signifies deeply realistic significance and reflects the author's meditation on human nature as well as the state of original civilization.

If we take people and natural environment as two members of the island society, the natural environment, namely the flora and fauna on the island, is obviously at a disadvantage. On the one hand, the flora was destroyed and polluted. On the desert island, children breathed the fresh air and enjoyed the primitive scenery. They used leafs to cover their body, picked wild berries to feed themselves, cut trees to set up huts, fired the dry branches to toast food, warm themselves and be a sign of asking help from outside world. The flora gave everything the children needed for their survival, whereas they brought serious pollution and destruction to the island. Firstly, all kinds of waste materials they brought polluted the circle of flora. For example, the plane wreckage which fell into the forest was heavy metal wastes that were pretty hard to eliminate. Besides, the suspended corpse of the pilot on the tree and the urine and excrement of the children under the trees were the household garbage that nobody tended to clear them away. In addition, they fired twice the flora of the island. It might be unconscious for the first fire. They fired the part of the forest because of the improper use of fire. But the second time was deliberate. Jack fired the whole forest for killing Ralph, which greatly slaughtered the flora. On the other hand, the fauna were also largely slaughtered by the children. They spent a large amount of time finding the traces of wild pigs. They hunted for wild pigs with extremely violent ways, fiercely stabbing with long spears, pricking several times with a knife and pressing with their body. The pack of hunters ignored the existence and development of animals, which was quite unfair for all the animals on the island. Therefore, we can see that the civilization of the desert island is pretty fragile when faced with the destruction caused by human beings.

\section{The Social Subjects in Lord of the Flies: Children}

The special social subjects which were described in the novel were a group of children who were trapped on the desert island because of the war. The oldest of them was 12 years old, while the youngest was only 6 . Children in transition period are faced with many self problems, which, in Erickson's view, are a combination of personal past experience and the problems facing the current cognitive context (ZHU, 1982). The reason why the author chose the children at this stage as protagonists is due to their immature thoughts and their unfamiliarity to the civilization of adult's world. Without the restraints from laws or civilizations, their inherent human nature will be completely exposed. Several different aspects of human nature are illustrated from main figures of the novel.

\section{The Representative Figure of Civilization: Ralph}

Ralph was a person who had some character that implied the civilization of human nature. He was the son of a naval officer. Besides, he was well cultivated and was capable enough of being a leader. During the life on the island, he summoned and organized other children by a conch which was a symbol of authority. For solving the problem of food, he arranged Jack to lead some children to hunt and he leaded other children to set up several huts made by the trunk of trees and grasses so as to settle down the problem of habitation. He always made efforts to establish effective rules to maintain the order of their life on the desert island. He was the organizer and maintainer of the civilized rules on the desert island and all of his practices were the shadow of 
the civilized society and its regulations. In addition, he also advocated that the fire should be kept so as to ask help from outside world, which illustrated his strong desire to come back to the civilized world.

However, the power of civilization he had was too naive and limited. When it came to the fear of the monster, instead of investigating, Ralph chose to assemble children together to vote, which aimed to decide whether there was a monster or not. It was a tease to the real democracy and also the misunderstanding for the real civilization. Moreover, there was also something gloomy and feeble in Ralph's heart. Simon's death could be partly attributed to the darkness and wilderness that hided under Ralph's heart and the death of Piggy further exposed Ralph's feebleness. So we can see that as the most authoritative spokesman of civilization, Ralph even couldn't correctly handle the power of civilization and control the darkness of his own deep heart. Faced with savagery and violence on the island, the reason and civilization are full of feebleness and weakness.

\section{The Representative Figure of Goodness and Reason: Simon}

Simon was a person who had kind heart, acute insight and clever mind, but without sound health, which also implied that both goodness and reason were pretty fragile compared to the savagery. We can see the goodness from Simon. On the desert island where was lack of food and water, Simon picked wild berries and distributed them to other children who were too young to catch them, which implied his generosity. Besides, he helped Piggy to find Piggy's glasses on the spot when his glasses were beaten away, which showed Simon's sympathy for the weak. What's more, he was quite clear that he would be in danger if he spoke out the truth of the monster, but he still tended to do it, which manifested his braveness in self-sacrifice for the truth. All of these illustrated that Simon could always rationally think and realize the nature of problems. It is Simon who firstly realized that the real monster was attached on our own body. He tended to speak out the truth about the monster without considering his own life just because he knew the only way to organize a civilized and orderly social life was to eliminate children's panic for the monster.

When heard of the things about the monster, Simon was the first one who dared to explore what the real monster was. And he was the only one who realized that evil was inherent in human nature. But when he went to salvage other children, he was violently killed as the monster by his own companions. All of the children on the desert island were the part of the lord of the flies, including Ralph and Piggy, and they all contained the gene of "killing you". So, the death of Simon was not an accident, but a murder case. For these children who were trapped, the only way to salvage them from madness and chaos was to keep their mind clear and rational and try their best to find the nature of all things. Unfortunately, it was just Simon who possessed this kind of ration on the desert island, but the other children shut door upon Simon's face. When Simon was killed, they killed the only person who could salvage them and the human nature was completely replaced by brutish nature. He was the person who symbolized the goodness in human nature and the reason that maintained civilized social relations. However, he was killed by crazy children when he tended to tell the truth about the monster. Just like the ethics and the reason that supported human society were eliminated, his death further enhanced the chaos and savagery of their life on the desert island. Therefore, we can see that the civilization of goodness and reason which Simon represents on the desert island is pretty fragile when faced with the wilderness of human nature.

\section{The Representative Figure of Wilderness: Jack}

As the representative figure of wilderness, Jack was a person who were capable of leading and were full of natural power. Hidden behind the dope and the mask, he continued more confidential personality. He was 
indulged in hunting and killing wild pigs, which fully showed his nature of the beast. Some activities like killing wild pigs and crazily dancing he leaded had efficiently satisfied their inherent desire of wilderness. Golding said that they just enjoyed the pleasure of conquering and killing and imposed their own will on others. With the expansion of wilderness, Jack regarded his companions as the objects to be killed. Moreover, under his influence, this kind of violence spread among the children. They killed Simon crazily, killed Piggy with a giant stone and made Ralph have no shelter with drastic fire.

Jack was a typical representative of wilderness. Meanwhile, the wilderness hided in everyone's deep heart and was the temptation that children couldn't refuse. So, children's wilderness in their deep heart was awakened when Jack activated. Like Vuuren said, The smoke that rises to the sky is like the incense that saints pray for(Vuuren, 2004). Eventually, the power of the wilderness gradually expanded and took the leading role. Jack's victory was the victory of wilderness when confronted with the civilization.

\section{The Reason Why the Civilization in Lord of the Flies was Destroyed}

In the end of the novel, the organized and orderly rules were gradually swollen by the savagery. Since the whole island was in fire, the wilderness ruled and defeated everything. On the one hand, the destruction of civilization firstly attributed to its fragility. On the other hand, it also resulted from the power of undefeatable evil savagery in people’s deep heart.

\section{The Fragility of Civilization and Reason in Hostile Environment}

When the children just fell into the island, there was still something civilized and rational on them. Led by Ralph, they worked together to try their best to maintain the order of the civilized society. They hunted for food, set up huts which were made by trees and grasses and kept the fire as a sign of asking help in an organized way. All of these manifested the civilization on them and their desire to come back to the civilized society.

Nevertheless, facing the hostile environment, their helplessness and fear which came to their own deep heart made them lose their minds gradually. The only thing they could do is to ask for help from the strong power of wilderness that hided in their deep heart. The hostile living environment, undefeatable and mysterious, made the children gradually abandon their well manners and lose their hope to come back to the civilized world and even made them lose their initial innocence and goodness, which implied the fragility of civilization and reason in the face of the undefeatable nature.

\section{The Savage and Wicked Power in the Depth of Human Nature}

The lord of the flies derives from the word "Baalzebub" from Hebrew language. "Baal" is considered as the worst of evils. The flies are the lord of all unclean things in English and they also show the wicked souls. In the novel, the lord of the flies symbolizes not only the filthy and suspended pig head, but also the darkest part of human nature. Evils hide in everyone's deep heart and the wilderness lurking inside the children can be awaken by the hostile environment. When tempted by the pleasure of irrational hunting, the influence of the civilization is weaken gradually.

It has great intention for Golding to put these children on an isolated island and let them develop naturally after their own natural instincts. The novel Lord of the Flies is an experimental novel used to experiment human nature. Golding drew the conclusion that human nature is evil by observing the experiment. Since groups and individuals are combined together in a common impulse rather than carefully expressing their respective interests separately, the form of self-interest in this group is manifested very clearly and causes a 
very serious consequence (WAN, 2004). Just like these children overcoming every difficulties of their survival problem through their clever intelligence, but they couldn't defeat the evils from their own instincts, which resulted in the occurrence of several tragedies. The shadow of western civilization went through the whole tragedy and the essence of the civilization was the war. Children fell into the desert island for escaping from the war. The development of all plots was expanded from the desire to the authority and bloodiness, which was similar to the situation in the war. Therefore, we can see that once we get rid of the restraints from regulations and civilizations, the nature of human civilization is pretty fragile and it's quite easy to become evil and savage. Like Golding's speech after the Nobel prize, he expressed his hope for the future of mankind. Human needs more humanity, more love. Some people want some kind of political system to do all this, while others want to create such a system with love. My belief is that the future of mankind lies between these two (LI, 1999).

\section{Conclusion}

Children's efforts to build a civilized utopia are in vain on the desert island where lack of restraints from civilizations. The civilization and democracy which Ralph represents are limited and incomplete and the goodness and reason which Simon represents are feeble and weak. So, when the savagery and violence which Jack represents stand out, all of the civilizations are destroyed. This novel shows us how fragile the civilization is when faced with the undefeatable nature and the summon of wilderness from people's deep heart. Besides, it also gives us a lesson that everyone should know himself or herself and face up to the cruelty and wilderness which hide in people's deep heart as well as eliminate their ignorance of their nature. Only we realize our own evils can we consciously control the evils and do something virtuous. In this way, people can awaken and set off to improve themselves.

\section{References}

DUAN, H. W., \& HUANG, Q. Q. (2007). Moral and ethical analysis of characters in Lord of the flies. Journal of Ningbo University (HUMANITIES AND SCIENCE EDITION), (06), 25-29.

LI, Y. H. (1999). Devoid of childlike innocence, devoid of human nature-Read Golding's Lord of the Flies. Foreign Literature Research, (1), 83-87.

van Vuuren, M. (2004). Good grief: Lord of flies as a post-war rewriting of salvation history. Literator, 25(2).

WAN, J. R., \& TANG, W. M. (2004). Western ethical classics in the twentieth century-Threshold of ethics: Morality and religion. Beijing: Renmin University of China press.

ZHU, Z. X. (1982). Review the history of child psychology. Beijing: Beijing Normal University Press. 